\title{
Prostate Cancer cT1b TNM Finding v8
}

National Cancer Institute

\section{Source}

National Cancer Institute. Prostate Cancer CT 1b TNM Finding v8. NCI Thesaurus. Code C140132.

Prostate cancer in which the tumor is an incidental histologic finding in more than 5\% of tissue resected. (from AJCC 8th Ed.) 